\title{
Nutritional status of schoolchildren
}

By A. E. Bender, Department of Nutrition, Queen Elizabeth College, Campden Hill, London $W 87 A H$

The assessment of deficiency diseases may be regarded as old-fashioned nutrition, as distinct from the modern concern with more sophisticated problems such as dietary interrelationships, treatment of genetic disease and the role of diet in such multifactorial disorders as heart disease, diverticular disease, spina bifida and a host of other disorders of the affluent communities.

However, it is still possible to question whether everyone in the lands of plenty is well nourished. Group mean values provide inadequate information; the problem is that of the individuals at the lower end of the scalc. However, it is extremely difficult to resolve the problem. Nutrient shortages are unlikely to be severe, biochemical indices may be in the normal or average range and clinical signs will certainly be very vague. Even if all three of these criteria indicate some degree of nutritional risk, it is difficult to demonstrate that extra nutrients confer any measurable benefit.

\section{Assessment of nutritional status}

Apart from the prevalence of frank deficiency disease, the usual indices of nutritional status of a community are perinatal death rates, average growth rates of children and average food consumption. For individuals the methods are far from satisfactory and comprise measurement of food intake, biochemical measurements and clinical assessment.

The nutrient intake of an individual would have to be considerably lower than the recommended daily intake (RDI) before giving cause for alarm. RDI's are intended as means of planning food supplies for communities and are, of course, $20 \%$ greater than average requirements.

In surveys in the United States, diets in which the intake of one or more nutrients falls below two-thirds of RDI are considered poor. In a survey in I955 the intake of $15 \%$ of households was poor by this criterion, but it is more significant that this figure increased to $20 \%$ in the 1965 survey (Eppright, Fox, Fryer, Lamkin, Vivian \& Fuller, 1972).

Biochemical measurements are, by themselves, of little value since they can show only that the subject is below average rather than below normal.

Clinical assessment as applied to children is not sharply defined. A child small 
for his age, with poor muscular development and poor muscle tone, thin, pale and with little desire for exercise, is described as being in a poor nutritional state. Such criteria are subjective and the difference between $0.68 \%$ of a sample of children in England and Wales suffering from this condition and $1.7 \%$ in Scotland may merely reflect different standards (Berry \& Hollingsworth, 1963).

The commonly-used criterion of nutritional status in children is their growth rate. Inadequate nutrition leads to poor growth; maximum growth rates require adequate nutrition. These two well-confirmed observations have led to a general belief that maximum growth rate of the young is an index and, indeed, the goal of nutritional perfection. Consequently, despite abundant evidence that, in experimental animals at least, restricted growth can lead to an extended life span, fast growth is often regarded as an index of good health. Stunting, however, can be caused by a variety of environmental factors and a variety of medical conditions, such as severe asthma, heart disease, renal and gastrointestinal disease and growth hormone deficiency, or may be genetically determined; small babies often remain smaller than average throughout childhood. Wolff \& Money (1973) reported growth rates of 10 $\mathrm{mm}$ per month when sleep was described as good, and growth at one-third of this rate during periods of poor sleep, due, it is claimed, to impaired rate of release of growth hormone. Widdowson (195I) showed that care and affection influence growth.

\section{Evidence of under-nutrition}

Clinically, in the Wcstern world, the only evidence of any significance is that of vitamin $\mathrm{D}$ deficiency and iron deficiency. Vitamin D deficiency, described as latent rickets, was shown in 'not less than $1 \%$ and probably $3 \%$ ' in a quasi-random survey of 500 infants in Glasgow in 1964 (Arneil, McKilligan \& Lobo, 1965). Anaemia was also found to be very frequent in this age group. Apart from individual special cases there is no evidence of general shortages of vitamins A, B group and C, protein, or minerals other than $\mathrm{Fe}$.

Cook, Altman, Moore, Topp, Holland \& Elliott (I 973 ), in a survey of 1298 children in England, reported that there was no clinical evidence of nutritional deficiency.

The only other direct evidence is based on the imprecise physical observations referred to earlier and described as 'poor nutritional state'. This was observed in $4.4 \%$ of children examined in 1950 and in $1.5 \%$ in 1955 . In 1956 the category was enlarged to include obesity, and 'unsatisfactory physical condition' was observed in $0.85 \%$ of children examined in $1960,0.38 \%$ in 1965 and $0.3 \%$ in 1969 (Darke, 1973).

\section{Inadequate nutrient intake}

Cook et al. (1973) carried out a survey on $77^{8}$ children between 1968 and 1970 using the $7 \mathrm{~d}$ weighing technique for individual children. With a few exceptions the mean intakes of energy and nine nutrients for seven groups of children reached, or closely approached, the British RDI.

However, the figures revealed enormous standard deviations in the intake of 
some nutrients, indicating that some children were consuming exceptionally small amounts of those nutrients (Fig. I). For example, the calculated average daily intake of vitamin $\mathrm{C}$ was $54 \mathrm{mg}$, compared with the RDI of $25 \mathrm{mg}$, apparently very satisfactory, but the standard deviation was $52 \mathrm{mg}$, meaning (if the distribution was normal) that one-sixth of the children were consuming less than $2 \mathrm{mg}$ vitamin $\mathrm{C} / \mathrm{d}$.

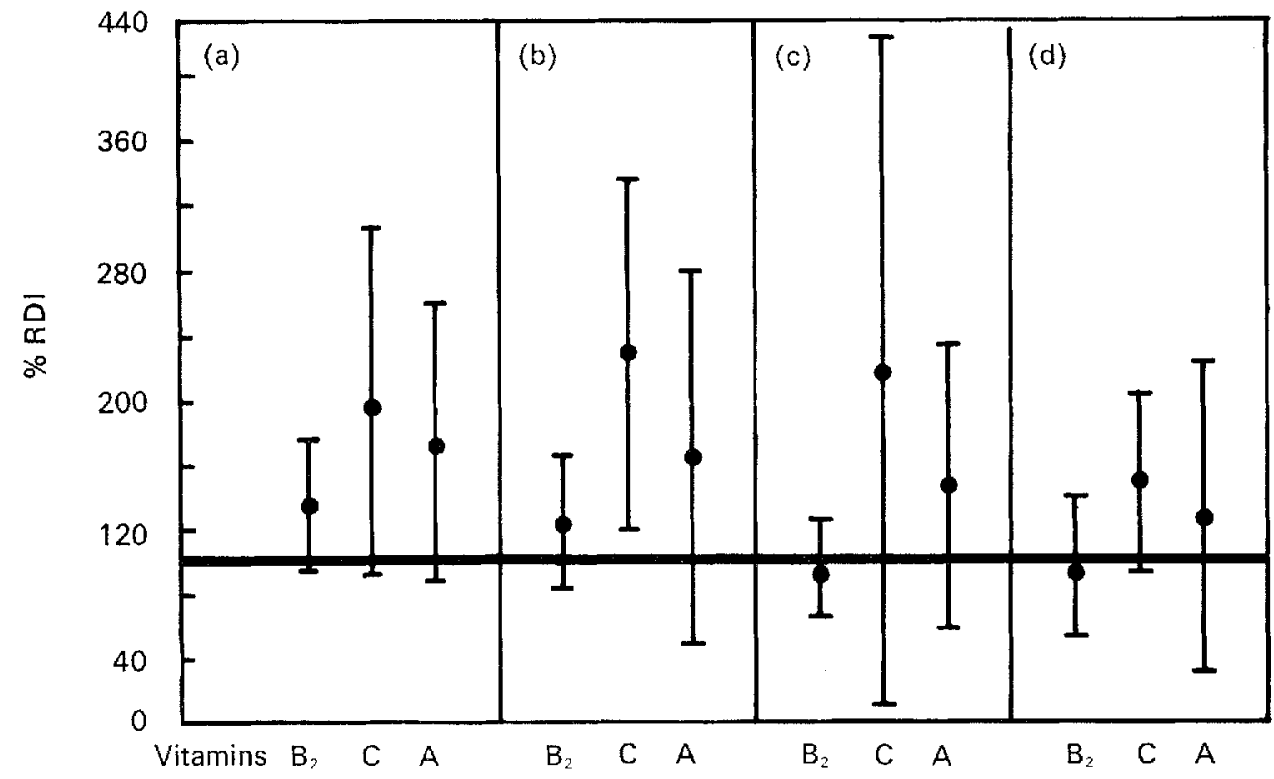

Fig. I. Mean daily intakes of vitamins, expressed as a percentage of the recommended daily intake (RDI), for various groups of children: (a) boys, 9-i i ycars old ( $\mathrm{n}=198)$; (b) boys, iz-i 4 years old (124); (c) girls, I2-I4 years old (I I ) ; (d) girls, I5-17 years old (8I). Vertical bars indicate standard deviation. Adapted from Cook, Altman, Moore, Topp, Holland \& Elliott ( 973 ).

A Swedish survey (Samuelson, Hrahnen \& Arvidsson, 1971) showed low $\mathrm{Fe}$ intakes for 13 -year-old children and low vitamin D intakes for all age groups. A survey of a village in New York State (Schorr, Sanjur \& Erickson, 1972) showed that approximately half the adolescents did not achieve two-thirds of the (US) National Research Council RDI for calcium, vitamin A and Fe.

\section{Nutrition and socio-economic status}

Poverty forces emphasis on the cheapest staple foods, with two results. First, a monotonous diet can result (as it often does in poor countries) in a restriction of food intake, leading to energy deficiency. Secondly, restriction of choice to the few cheap foods will restrict nutrient intake.

In the I930's, poverty and under-nutrition were closely associated when unenriched white bread, unenriched margarine and sweetened condensed milk constituted a large part of the diet of the poorer people. 
At present, the relation between socio-economic class and nutritional status is not nearly as marked, if only because relative poverty is not so severe; white bread and margarine are enriched and the total amount of nutrients available, especially protein, is greater.

In poor families the percentage of available money spent on food is high, and factors that reduce the available money even slightly can have a marked effect on food purchases and ultimately on health. One of the earliest and most dramatic of these observations was that of McGonigle (1933) at Stockton-on-Tees from I923 to 1932. Families moved into superior housing suffered an increased death rate (rising from 23 to 33 per thousand) compared with the control area. They had only a small, fixed sum of money available for buying food and the increased death rate was explained by the increased rental in the new housing, which reduced the amount of money available for food by $23 \%$.

If growth is used as a criterion of nutritional status, socio-economic differences are revealed by records of heights of school boys of the 13-14-year age group. Those from public schools showed little change between 1937 and 1957 , while those of London County Council (LCC) school boys increased steadily over the years. By 1957 , the LCC boys were still about $400 \mathrm{~mm}$ shorter than the public school boys (Berry \& Hollingsworth, 1963).

Table I. Relationship between height and weight and social class in girls aged I 8-2 I years

\begin{tabular}{|c|c|c|c|c|c|}
\hline \multirow{2}{*}{$\begin{array}{l}\text { Social } \\
\text { class }\end{array}$} & \multicolumn{2}{|c|}{ Height } & \multicolumn{2}{|c|}{ Weight } & \multirow[b]{2}{*}{$\begin{array}{l}\text { Pondera } \\
\text { index }\end{array}$} \\
\hline & $(\mathrm{m})$ & (in) & $(\mathrm{kg})$ & (lb) & \\
\hline I & $1 \cdot 627$ & 64.08 & $58 \cdot 10$ & $128 \cdot 10$ & $12 \cdot 75$ \\
\hline 2 & $I \cdot 63 \mathrm{I}$ & $64 \cdot 21$ & $57 \cdot 76$ & $127 \cdot 33$ & $12 \cdot 79$ \\
\hline 3 & $1 \cdot 624$ & $63^{\prime} \cdot 92$ & 57.77 & 127.35 & 12.75 \\
\hline 4 & 1.613 & $63 \cdot 49$ & $5^{8 \cdot 69}$ & 129.39 & $12 \cdot 60$ \\
\hline 5 & $1-600$ & 63.00 & $56 \cdot 3^{x}$ & $124 \cdot 15$ & $12 \cdot 60$ \\
\hline
\end{tabular}

From Dann \& Roberts (1969).

Table 2. Mean heights and weights of groups of boys and girls expressed as a percentage of average for same age

\begin{tabular}{|c|c|c|c|c|}
\hline & No. & School & Height & Weight \\
\hline Boys & $\begin{array}{r}1440 \\
632 \\
197\end{array}$ & $\begin{array}{l}\text { Modern } \\
\text { Grammar } \\
\text { Royal } \\
\text { Naval College }\end{array}$ & $\begin{array}{r}99 \cdot 1 \\
103 \cdot 3 \\
106 \cdot 2\end{array}$ & $\begin{array}{r}99 \cdot 3 \\
103 \cdot 2 \\
106 \cdot 5\end{array}$ \\
\hline Girls & $\begin{array}{r}1654 \\
690\end{array}$ & $\begin{array}{l}\text { Modern } \\
\text { Grammar }\end{array}$ & $\begin{array}{r}98 \cdot 9 \\
104 \cdot 2\end{array}$ & $\begin{array}{r}99.4 \\
103.6\end{array}$ \\
\hline
\end{tabular}

From Sutcliffe \& Canham (I950).

Eppright et al. (1972) reported that heights, weights and body circumference were greater in the richer groups, but skinfold thicknesses were greater in the poorer groups, i.e. they were fatter (see also Tables I and 2). 
Cooke et al. (I973) found that social class was not, in general, associated with highly significant differences in average nutrient intakes.

There was a significant fall in animal protein intake in passing from the higher to the lower social groups, but the differences were small, the intakes being 43,42 , 39 and $39 \mathrm{~g} / \mathrm{d}$ respectively in the four social groups. Total protein figures were 66 , 66,63 and $63 \mathrm{~g} / \mathrm{d}$ respectively and the differences were not significant. There was a significant fall in riboflavin intake but again the differences were small, the intakes being $\mathrm{I} \cdot 6, \mathrm{I} \cdot 7, \mathrm{I}_{5} 5$ and $\mathrm{I} \cdot 5 \mathrm{mg} / \mathrm{d}$. There were no significant differences between intakes of $\mathrm{Ca}, \mathrm{Fe}$, and vitamins $\mathrm{B}_{1}$, nicotinic acid, $\mathrm{B}_{6}, \mathrm{C}$ and $\mathrm{D}$.

In a nationwide American survey (Eppright et al. I972), 3.5\% of the pre-school children of the low-income areas had retarded growth according to wrist X-rays; $\mathrm{Fe}$ intakes were low in $60 \%$ of the children, anaemia occurred in $33 \%$ of those under 6 years old, low serum vitamin A occurred in $33 \%$, low ascorbic acid intake occurred in $15 \%$ and vitamin D deficiency occurred in $3.7 \%$ of the sample.

There are many other related factors. For example, food intake can depend on the number of siblings (Cook et al. 1973), and family size and educational status of parents (Ministry of Health, I968). Height, so often used as an index of nutritional status, can depend on birth weight and differences persist throughout childhood; birth weight can be reduced if mothers smoke (Davie, Butler \& Goldstein, I972), and finally, to complicate the picture, smoking increases with falling social class.

There are obviously many other environmental factors that will affect food intake even when an adequate diet is available. A series of observations from Hungary (Tarjan, I973) showed $30 \%$ wastage of food from a fixed menu, but only $5 \%$ when the menu was self-selected. This is common experience in many areas. In the UK school meals service, many older children are allowed to select their foods, but there is the possibility of selecting a nutritionally inferior diet.

A 6-year survey in France demonstrated wastage resulting from environmental conditions (Tracq \& de Kytspotter, I969). Children left food 'because they were busy scuffling and chattering and because they were bored by the noise and crowding . . . 'Well-cooked food was rejected while children ate bread if they were hungry'.

The omission of breakfast appears to be common. A Canadian survey (Robson, 1971) showed that $30 \%$ of the children had no breakfast; the figure in a Japanese survey (Morita, I 972) was $58 \%$ of women students; Lynch (I969) reported $24 \%$ in London, and Darke (1973) reported $10 \%$ in junior schools and $21 \%$ in the $\mathrm{I}_{4}-1$ 5year age group. We found (Bender, Magee $\&$ Nash, 1972 ), in a survey of 800 children in Essex, that $4 \%$ of the infants, $6 \%$ of the infant-junior age group, $6 \%$ of junior and $14 \%$ of seniors had no breakfast (nothing more than tea or coffee). In Hungary (Tarjan, 1973) the figures were $13 \%$ for children living at home and $50 \%$ for students boarding at college.

\section{School meals}

School meals can clearly play a large part in levelling up nutrient intakes. The school meal in the UK is intended to provide half the daily RDI of protein and ${ }_{33}(\mathrm{r})_{4}$ 
one-third of the energy; the intention is not always achieved (Bender et al. 1972). In Japan, where school meals are said to have played a major role in increasing the heights and weights of schoolchildren over preceding generations, the meal is intended to provide one-third of the energy, three-eighths of the protein, half the vitamins $A$ and $C$, and three-fifths of vitamins $B_{1}$ and $B_{2}$ (Shimazono, 1973). The increased heights and weights were shown to be positively correlated with intakes of fat, $\mathrm{Ca}$, both total and animal protein, and vitamins $A$ and $B_{2}$.

\section{Conclusion}

Since, in the Western countries, we have to search not only for mild undernutrition but even for the early warning signs of reduced nutrient intake, it might be doubted whether there is any problem. However, an editorial in the British Medical Journal (r973) states: 'that there may still be room for improvement in childhood nutrition is apparent from recent reports that children of social class 5 born in $195^{8}$ were, on average, $33 \mathrm{~mm}$ shorter than children from social classes $I$ and 2 at the age of 7 .

It has been suggested (Schaefer \& Johnson, I969) that under the conditions of mild deprivation observed in the West the subjects are protected by the general health services, and that if the malnourished children found in the poorer communities of the USA were transplanted to a backward country where medical services are lacking there would be prompt evidence of partial or near starvation.

\section{REFERENCES}

Arneil, G. C., McKilligan, H. R. \& Lobo, E. (1965). Scott. med. F. ro, 480.

Berry, W. 'T. C. \& Hollingsworth, D. F. (1963). Proc. Nutr. Soc. 22, 48.

Bender, A. E., Magee, P. \& Nash, A. H. (1972). Br. med. $\mathcal{F}$. ii, $38_{3}$.

British Medical Journal (I973). Br. med. 7 . iv, i 83 .

Cook, J., Altman, D. G., Moore, D. M. C., Topp, S. G., Holland, W. W. \& Elliott, A. (1973). Br. J. prev. soc. Med. 27, 9 r.

Dann, T. C. \& Roberts, D. F. (r969). Br. J. prev. soc. Med. 23, 65.

Darke, S. (1973). Feeding the Family at Home and at School. London: British Committee of the International Union of Family Organisation.

Davie, R., Butler, N. R. \& Goldstein, H. (I972). From Birth to Seven. London: Longmans.

Eppright, E. S., Fox, H. M., Fryer, B. A., Lamkin, G. H., Vivian, V. M. \& Fuller, E. S. (1972). Wld Rev. Nutr. Diet. 14, 269.

Lynch, G. W. (1969). Med. Offr 121, 4 I.

McGonigle, G. C. M. (1933). Proc. R. Soc. Med. 26, 677.

Ministry of Health (I g68). Rep. publ. Hlth med. Subj., Lond. No. I 18.

Morita, M. (1972). fap. F. Nutr. 30, 67.

Robson, R. H. (1971). Can. Home Econ. J. 21, 14.

Samuelson, G., Irahnen, H. \& Arvidsson, E. (1971). Am. F. clin. Nutr. 24, 136r.

Schaefer, A. E. \& Johnson, O. C. (1969). Nutr. Today 4, 2.

Schorr, B. C., Sanjur, D. \& Erickson, E. C. (1972). $\mathscr{F}$. Am. diet. Ass. 61, 415.

Shimazono, N. (r973). Fap. Biblthca Nutr. Diet. I8, 267.

Sutcliffe, A. \& Canham, J. W. (1950). Heights and weights of boys and girls. London: John Murray.

Tarjan, R. (1973). Biblthca 'Nutr. Dieta' 18, 280.

Tracq, M. F. \& de Kytspotter, M. (1969). Bull. Soc. scient. Hyg, aliment. 57, 274.

Widdowson, E. M. (1951). Lancet i, I316.

Wolff, G. \& Money, J. (1973). Psychol. Med. 3, г8. 